
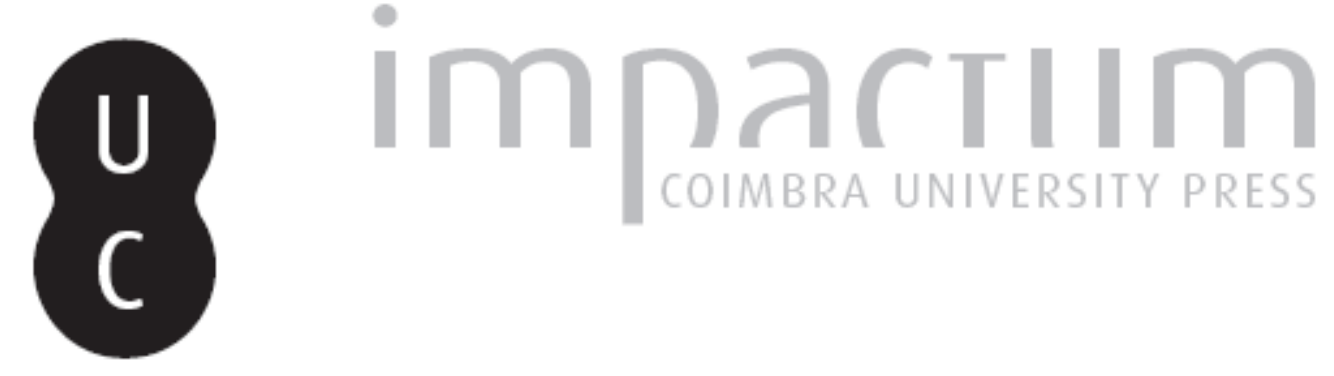

\title{
The reception of penicillin in Portugal during World War II: cooperation with Brazil and the United States of America
}

Autor(es): $\quad$ Bell, Victoria; Pereira, Ana Leonor; Pita, João Rui Publicado por: Centro de Informação Europe Direct de Aveiro; Centro de Estudos

URL

persistente:

DOI: $\quad$ DOI:http://dx.doi.org/10.14195/1647-6336_13_9

Accessed : $\quad$ 26-Apr-2023 13:30:00

A navegação consulta e descarregamento dos títulos inseridos nas Bibliotecas Digitais UC Digitalis, UC Pombalina e UC Impactum, pressupõem a aceitação plena e sem reservas dos Termos e Condições de Uso destas Bibliotecas Digitais, disponíveis em https://digitalis.uc.pt/pt-pt/termos.

Conforme exposto nos referidos Termos e Condições de Uso, o descarregamento de títulos de acesso restrito requer uma licença válida de autorização devendo o utilizador aceder ao(s) documento(s) a partir de um endereço de IP da instituição detentora da supramencionada licença.

Ao utilizador é apenas permitido o descarregamento para uso pessoal, pelo que o emprego do(s) título(s) descarregado(s) para outro fim, designadamente comercial, carece de autorização do respetivo autor ou editor da obra.

Na medida em que todas as obras da UC Digitalis se encontram protegidas pelo Código do Direito de Autor e Direitos Conexos e demais legislação aplicável, toda a cópia, parcial ou total, deste documento, nos casos em que é legalmente admitida, deverá conter ou fazer-se acompanhar por este aviso.

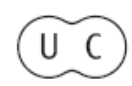


DEBATER

A EUROPA



jul-dez 2015
A (DES) CONSTRUÇÃO DA EUROPA
(1939-1945)
(DE) CONSTRUCTING EUROPE (1939-1945) 


\title{
The reception of penicillin in Portugal during World War II: cooperation with Brazil and the United States of America
}

\author{
Victoria Bell \\ Visiting Professor at the Faculty of Pharmacy-UC \\ Research Fellow at the Interdisciplinary Research Centre of the Twentieth \\ Century University of Coimbra - CEIS20 \\ E-mail: victoriabell1103@gmail.com \\ Ana Leonor Pereira \\ Professor at the Faculty of Letters \\ Research Fellow at the Interdisciplinary Research Centre of the Twentieth \\ Century University of Coimbra - CEIS20 \\ E-mail: aleop@ci.uc.pt \\ João Rui Pita \\ Professor at the Faculty of Pharmacy-UC \\ Research Fellow at the Interdisciplinary Research Centre of the Twentieth \\ Century University of Coimbra - CEIS20 \\ E-mail: jrpita@ci.uc.pt
}

\begin{abstract}
The discovery of penicillin in 1928 and its introduction as therapeutic agent in the 1940's significantly altered the prognosis of infectious diseases and represented the starting point for research that led to the discovery of other antibiotics. Portugal was one of the first European countries, non-participant in the II World War, to obtain penicillin for civilian use. World production of the antibiotic was scarce and military forces and
\end{abstract}


government appointed research centers absorbed the limited amount available. Good diplomatic relations between Portugal, Brazil and the United States of America (USA) were decisive in attaining penicillin for our country. In May of 1944, the Brazilian government offered Portugal 12 vials of penicillin. During the summer of 1944, as the Portuguese and American governments negotiated the use of the Lages military base in the Azores, they also discussed the terms regarding a regular supply of penicillin for Portugal. In order to import penicillin from the USA, Portugal was obliged to establish a controlling committee to oversee the allocation and distribution of the antibiotic. The Portuguese Red Cross played a major role in this event, on July 26, 1944 the humanitarian institution appointed the Junta Consultiva para a Distribuição de Penicilina em Portugal (JCDPP) to act as a controlling committee. The first allotment of 700 vials, each containing 100000 units of penicillin, arrived at Lisbon airport on September 8, 1944. In January 1945, the US government increased the monthly allotment to 1000 vials and in March 1945 to 1500 vials. As world production of penicillin increased, controlling committees were no longer necessary. In June 1945, the Portuguese Red Cross terminated the JCDPP and the Portuguese pharmaceutical industry began to import the antibiotic. Cooperation with Brazil and the USA was vital for Portugal to attain penicillin. It enabled the antibiotic to become available to the Portuguese civilian population when its use was still restricted to the military forces. The in advanced acquisition of penicillin in Portugal that resulted from nation cooperation saved many lives to and initiated a new era in the treatment of infectious diseases.

Keywords: Penicillin; Portuguese Red Cross; World War II; Brazil; United States of America

\section{Introduction}

Industrial production of penicillin ${ }^{1}$ began in $1942^{2}$. During 1943 and the beginning of 1944 overall production of the antibiotic was scarce and the military forces absorbed most of the available quantities ${ }^{3}$.

\footnotetext{
${ }^{1}$ The present study results of the doctoral research project (Doctoral fellowship SFRH/BD/62391/2009) from Fundação para a Ciência e a Tecnologia - FCT. Group of History and Sociology of Science and Technology Interdisciplinary Studies Center of the twentieth century the University of Coimbra - CEIS20 / Grupo de História e Sociologia da Ciência e da Tecnologia do Centro de Estudos Interdisciplinares do Século XX da Universidade de Coimbra - CEIS20 (UID/HIS/00460/2013). Acknowledgements: Fundação para a Ciência e a Tecnologia - FCT; Cruz Vermelha Portuguesa (Lisboa).
} 
In Portugal, even before it was available, patients in life threatening situations due to the severity of their illness regarded penicillin as "the last hope of salvation" Family members and patient physicians sent innumerous appeals to the Portuguese Red Cross requesting penicillin ${ }^{5}$. In response to these requests, the acquisition of penicillin for Portugal became a priority for the Portuguese humanitarian institution ${ }^{6}$. In hope of obtaining penicillin, the Portuguese Red Cross contacted Brazil, the United States of America and Great Britain ${ }^{7}$. Great Britain acknowledged the request but was unable to assist $^{8}$ the United States were also incapable to satisfy this request ${ }^{9}$. Brazil, after some insistence from the Portuguese Red Cross, complied and sent twelve vials of penicillin to Portugal ${ }^{10}$. The first vials of penicillin arrived in our country on the May 24, 1944, offered by the Brazilian Red Cross ${ }^{11}$.

As production of penicillin increased, civilian distribution of the therapeutic agent became possible ${ }^{12}$. However, as the existing supplies were limited, Controlling Committees became necessary to oversee the distribution of the antibiotic ${ }^{13}$.

To our knowledge, the Civilian Penicillin Distribution Unit ${ }^{14}$ established in the USA, on May 1, 1944, was the first installed controlling committee. Later, European

\footnotetext{
${ }^{2}$ WAINWRIGHT, M. - The history of the therapeutic use of crude penicillin, Medical History. 7273. 31:1 (1987), pp. 41-50. ISSN 0025-7273.

3 'Penicillin: A Wartime Accomplishment', Chemical \& Engineering News, 23,24 (1945), pp. 23102316.

${ }^{4}$ ARQUIVO DA CRUZ VERMELHA PORTUGUESA - Carta Enviada À Cruz Vermelha Brasileira Em 27 de Março 1944, Número de Ordem 1368', Livro de Correspondência Expedida, Volume III (Lisboa, 1944).

${ }^{5}$ ARQUIVO DA CRUZ VERMELHA PORTUGUESA - Carta Enviada À Embaixada Do Brasil Em 27 de Março 1944 - Número de Ordem 1374', Livro de Correspondência Expedida, Volume III. Lisboa, 1944.

${ }^{6}$ Ibid.

${ }^{7}$ ARQUIVO DA CRUZ VERMELHA PORTUGUESA - Ata Da Sessão Ordinária Da Comissão Central Da Cruz Vermelha Portuguesa Em 8 de Maio de 1944', Livro de Atas Da Comissão Central Da Cruz Vermelha Potuguesa. Lisboa, 1944.

${ }^{8}$ ARQUIVO DA CRUZ VERMELHA PORTUGUESA - Carta Da Embaixada Britânica de 09 de Maio de 1944 - Número de Ordem de Entrada 1800', Livro de Correspondência Recebida. Lisboa, 1944.

${ }^{9}$ ARQUIVO DA CRUZ VERMELHA PORTUGUESA - 'Carta Da Legação Dos Estados Unidos Da América de 19 de Abril de 1944 - Número de Ordem de Entrada 1445', Livro de Correspondência Recebida. Lisboa, 1944.

10 ARQUIVO DA CRUZ VERMELHA PORTUGUESA - 'Ata Da Sessão Ordinária Da Comissão Central Da Cruz Vermelha Portuguesa Em 12 de Junho de 1944', Livro de Atas Da Comissão Central Da Cruz Vermelha Potuguesa. Lisboa, 1944.

${ }_{11}$ ARQUIVO DA CRUZ VERMELHA PORTUGUESA - 'Telegrama Enviado À Cruz Vermelha Brasileira Em 24 de Maio 1944', Livro de Correspondência Expedida. Lisboa, 1944.

12 'Penicillin: A Wartime Accomplishment', op. cit..

${ }^{13}$ ARQUIVO DA CRUZ VERMELHA PORTUGUESA - 'Carta Enviada Ao Dr. Armando Luzes Em 12 de Julho 1944 - Número de Ordem 3505', Livro de Correspondência Expedida, Volume VIII. Lisboa, 1944.

${ }^{14}$ LESCH, John E. - The First Miracle Drugs: How the Sulfa Drugs Transformed Medicine. New York: Oxford University Press, 2007. p. 224. ISBN 139780195187755.
} 
countries such as France, Spain and Portugal established equivalent committees to supervise penicillin distribution. Portugal established, the Junta Consultiva para a Distribuição da Penicilina em Portugal in Portugal, in July $1944^{15}$, Spain established, The Comité de la penicilina, in September 1944, and in January 1945, France established, The Comité de distribuição da penicilina.

Although the main goal of the controlling committees was to supervise allocation and distribution of the scarce amount of penicillin available for civilian use, the procedures implemented in each country were different.

The reception of penicillin in Portugal, the countries and the institutions involved must be perceived in the context of World War II and in the political context associated with the dictatorship of António Oliveira Salazar. Portugal officially assumed a neutral position in World War II. However, in spite of this fact, Portugal became a country of substantial spy activity. It was also a country where intense diplomatic relations were developed. Portugal was a passing point for numerous war fugitives, some of which took up residency in this country. According to Luís Reis Torgal, after WWII, the Portuguese president António Oliveira Salazar tried to explain that the neutral position assumed by Portugal was in fact a "neutral collaboration" with the allied countries (after 1942-1943) even though he admitted some comprehension toward the German situation ${ }^{16}$.

It seems important to refer that several science historians have studied the discovery of penicillin, its industrial production and its reception in different countries ${ }^{17}$. The study presented derived from a larger project concerning the reception

\footnotetext{
15 ARQUIVO DA CRUZ VERMELHA PORTUGUESA - 'Carta Enviada À Delegação Da Cruz Vermelha Portuguesa de Estremoz Em 20 de Setembro 1944 - Número de Ordem 4524', Livro de Correspondência Expedida, Volume X. Lisboa, 1944.

${ }^{16}$ See TORGAL, Luís Reis - Estados Novos, Estado Novo. Vol. 2. Coimbra: Imprensa da Universidade de Coimbra, 2009, p. 538, ISBN 978-989-8074-60-7. Ver sobre o mesmo assunto: CARRILHO, Maria et al - Portugal na Segunda Guerra Mundial: contributos para uma reavaliação. Lisboa: Dom Quixote, 1989, ISBN 972-20-0755-6 e TORGAL, Luís Reis; PAULO, Heloísa (coords.), Estados autoritários e totalitários e suas representações. Coimbra: Imprensa da Universidade de Coimbra, 2008, ISBN 979989-8074-53-9

${ }^{17}$ See, e.g.: HELFAND, W. H. et al.- "Wartime industrial development of penicillin in the United States." In: PARASCANDOLA, John - The history of antibiotics. A Symposium. Madison: American Institute of the History of Pharmacy, 1980. ISBN 100931292085 ISBN 13 9780931292088. pp. 31-56; LAX, Eric - The Mold in Dr. Florey's Coat. The story of the penicillin miracle. New York: Owl Books, 2005. ISBN-13 978-0805077780; ISBN-10 0805077782; LEDERMANN, Walter D. - "La historia de la penicilina y de su fabricación en Chile", Revista Chilena de Infectología 23:2 (2006), pp. 172-176; BUD, Robert - Penicillin Triumph and Tragedy, Oxford: Oxford University Press, 2007, ISBN 978-19925406-4; GROSSMAN, Charles M. - "The First Use of Penicillin in the United States", Annals 
of penicillin in Portugal, it involved research of written sources and archival material, that is accessible in the Arquivo da Universidade de Coimbra and in the Arquivo da Cruz Vermelha Portuguesa in Lisbon ${ }^{18}$.

\section{United States of America - Civilian Penicillin Distribution Unit}

The Civilian Penicillin Distribution Unit, established in Chicago by the War Production Board (WPB) ${ }^{19}$, began functioning on 1 May 1944 and ceased its activity on 15 March 1945. This council devised and implemented strategies that enabled an even distribution of the limited amount of penicillin available, in civilian population.

The Civilian Penicillin Distribution Unit established an advisory council, composed of appointed representatives of $\mathrm{OSRD}^{20}$, the U. S, Public Health Service, WPB, and the American Medical Association, to select 1000 hospitals to receive monthly allotments of penicillin for civilian use $\mathrm{e}^{21}$. The supply of penicillin allocated to these depository hospitals enabled them to treat their patients and to distribute the

of Internal Medicine, 149 (2008), pp. 135-136; SANTESMASES, M. J. - "Distributing Penicillin: the clinic, the hero and industrial production in Spain, 1943-1952". In: QUIRKE, V.; SLINN, J. (eds.) - Perspectives on Twentieth-Century Pharmaceuticals. Oxford: Peter Lang, 2010, ISBN 978-3-03910-920-3 pp. 91-118; SANTESMASES, M. J. - "Screening antibiotics: industrial research by CEPA and Merck in the 1950s", Dynamis, 31:2 (2011), pp. 407-427; GONZÁLEZ BUENO, Antonio; RODRÍGUEZ NOZAL, Raul; TEIJÓN, Carlos José Pérez "La penicilina en Espanã: difusión, propriedad industrial y negocio, en clave autárquica (19441959)", Estudos do Século XX, 12 (2012), pp. 271-287; RODRIGUEZ NOZAL, Raul "El despacho de penicilina en la España: de las restricciones y el estraperlo", Revista Panacea Humanidades, Ciencia y Sanidad, 1:Janeiro (2015), pp. 14-15.

${ }^{18}$ See: BELL, V., PITA, J. R.; PEREIRA, A. L. - "A importância do Brasil no fornecimento das primeiras doses de penicilina para Portugal (1944)". In: FIOLHAIS, C.; SIMÕES, C.; MARTINS, D. (eds.), Congresso Luso-Brasileiro de História das Ciências, Livro de Actas. Coimbra, Universidade de Coimbra2011, ISBN 978-989-26-0122-9. pp. 878-891; BELL, Victoria; PITA, João Rui; PEREIRA, Ana Leonor - "Circuitos e redes de distribuição da penicilina em Portugal: 1944-1946. In: MALAQUIAS, Isabel et al. - Construir Ciência - Construir o Mundo. Aveiro: UA Editora - Universidade de Aveiro, 2014, pp. 143-145; BELL, Victoria - Introdução dos antibióticos em Portugal: ciência, técnica e sociedade (anos 40 a 60 do século XX). Coimbra: Tese de doutoramento - Universidade de Coimbra, 2014.

${ }^{19}$ War Production Board (WPB) -Established by Presidential Executive Order 9024 on January 16, 1942. The WPB main objectives were to supervise war procurement and production programs. Line b) of Executive Order 9024 states that the WPB should: "Determine the policies, plans, procedures, and methods of the several Federal departments, establishments, and agencies in respect to war procurement and production, including purchasing, contracting, specifications, and construction; and including conversion, requisitioning, plant expansion, and the financing thereof; and issue such directives in respect thereto as he may deem necessary or appropriate".

${ }^{20}$ Office of Scientific Research and Development (OSRD) - United States federal government agency created on June 28, 1941 by Presidential Executive Order 8807. The ORSD purpose was to coordinate and support scientific and medical research for military purposes during World War II.

21 'Penicillin: A Wartime Accomplishment', op. cit. 
antibiotic to other hospitals in their vicinity. The location the hospital, the number of existing beds, the rate of admission and the population served, were some of the major factors that determined the amount of penicillin consigned monthly to each healthcare unit $^{22}$. The WPB informed all US hospitals of the required procedures to attain penicillin and the location of the assigned depository hospitals. In order to avoid incorrect use and enlighten physicians on the most efficient way to use penicillin, Dr. Chester Keefer ${ }^{23}$, of the Committee on Medical Research of Office of Scientific Research and Development, prepared "The Use, Indications, Contraindications, and Mode of Administration of Penicillin" ${ }^{24}$. This elaborate report, informed physicians of the infectious diseases most susceptible to penicillin treatment, advised them on the best route of administration for the antibiotic as well as the possible side effects that may occur. The WPB distributed copies of Dr. Keefer's report to hospitals and private physicians $^{25}$. Between May 1, 1944 and March 15, 1945 (when terminated) the Civilian Penicillin Distribution Unit distributed over 250 billion units of penicillin to 8000 hospitals and other healthcare units in the United States, Alaska, Puerto Rico, Hawaii, and the Virgin Islands ${ }^{26}$.

\section{Controlling Committees in Europe: Spain and France}

As penicillin production increased and larger amounts of the therapeutic agent became available, the USA began to export the antibiotic to friendly and neutral countries. In order to supervise penicillin distribution, the US Foreign Economic Administration obliged the requisitioning countries to establish controlling committees $^{27}$. From June 1944 to August 1945, the USA exported over 750 billion units of penicillin to these countries ${ }^{28}$.

\footnotetext{
${ }^{22} \mathrm{Ibid}$.

${ }^{23}$ Chester Scott Keefer, M.D., D.Sc. (1897-1972). During World War II, Dr. Chester Keefer was appointed Chairman of the National Research Council's Committee on Chemotherapeutics and Other Agents and Medical Administrative Officer of the Committee on Medical Research of the Office of Scientific Research and Development. One of Dr. Keefer's main assigned duties was to supervise and control distribution and allocation of penicillin for civilian use in the United States during World War II.

24 'Penicilina Em Portugal' - Jornal Do Médico, 4, 93 (1944), p. 709.

25 'Penicillin: A Wartime Accomplishment', op. cit.

26 Ibid

27 ARQUIVO DA CRUZ VERMELHA PORTUGUESA - 'Carta Enviada Ao Dr. Armando Luzes Em 12 de Julho 1944 - Número de Ordem 3505', op. cit.

28 'Penicillin: A Wartime Accomplishment', op. cit.
} 
France - Commission de la Pénicilline:

After liberation from German occupation, in 1944, France negotiated with the USA a regular supply of penicillin for civilian use. The first allotment of 500 vials of the antibiotic arrived in France in January $1945^{29}$.

In order to ensure the equitable distribution of the antibiotic and in accordance with the recommended therapeutic indications, the French Ministère de la Santé Public (French Ministry of Health) constituted the Commission de la Pénicilline. The committee decided to allocate the amount of penicillin supplied to previous selected hospitals that would function as "therapeutic centers". Patients diagnosed with pathologies susceptible to the antibiotic were transported to the designated centers to receive treatment. With this measure, the commission ensured an even distribution of penicillin among patients. It also guaranteed the correct use of the therapeutic agent and minimized transportation difficulties. In February 1945, six therapeutic centers functioned in France, three in Paris and three in the province. By February 1946, 600 centers operated in the country and in April 1946, every hospital in France treated patients with penicillin ${ }^{30}$.

\section{Spain - Comité Nacional de la Penicilina}

In September 1944, Spanish government negotiated with its American counterpart a regular supply of penicillin for Spain. The Spanish Consejo Nacional de Sanidad nominated a technical committee, the Comité Nacional de la Penicilina, to control penicillin import, distribution and use in Spain. Four members composed the appointed committee, a physician, Carlos Jimenez Diaz, a pharmacist, Nazario Diaz Lopez, a bacteriologist, Gerardo Clavero del Campo and a dermatologist, Enrique Alvarez Sainz ${ }^{31}$. The Comité Nacional de la Penicilina determined to allocate penicillin supplies to previous appointed pharmacies - farmácias depositarias. The committee devised directives for patients and physicians who wished to requisition penicillin. The requisitioning parties had to provide the committee with a complete medical history of the patient. Appointed physicians by the Comité Nacional de la Penicilina analysed the

\footnotetext{
${ }^{29}$ MINISTÈRE DE LA SANTÉ PUBLIQUE - Thérapeutique Par La Pénicilline. Primiere ed. Paris: Masson et Cie, Éditeurs, 1947. p. XIV.

${ }^{30}$ Ibid.

${ }^{31}$ GONZÁLEZ BUENO, Antonio; RODRIGUEZ NOZAL, Raul - 'La penicilina en la España franquista: importación, intervención e industrializaciónitle'. Revista EIDON. 2002. ISSN 2174-8292. 38.
} 
patients file and if approved the requisitioning party received a voucher that enabled him to acquire a designated amount of penicillin form a "farmácia depositária"32

\section{Junta Consultiva para a Distribuição de Penicilina em Portugal}

In May 1944, the Brazilian government offered Portugal 12 vials of penicillin. Even though the amount of antibiotic provided by the Brazilian government sufficed to save a life, the meagre amount supplied could not fulfill Portugal's needs. The Portuguese Red Cross knew that a regular supply of penicillin was required in order to satisfy the innumerous requests received. Acting on this intent, they once more appealed to the United States of America ${ }^{33}$. On May 5, the United States Red Cross delegate informed the Portuguese institution that it might be possible to supply Portugal with penicillin $^{34}$ and on July 1 requested a meeting to discuss the matter ${ }^{35}$. The American government requested that the Portuguese Red Cross establish a controlling committee to analyse requests and oversee the distribution of penicillin in Portugal $^{36}$.

In order to fulfill the request entailed by the United States government, the Portuguese Red Cross established the Junta Consultiva para a Distribuição da Penicilina em Portugal (Consultive Committee for the Distribution of Penicillin in Portugal) ${ }^{37}$. This committee was composed of five medical doctors, Professor Doutor Francisco Gentil (presidente), Dr. Luís António Xavier Júnior (secretary), Professor Doutor Fernando da Fonseca, Professor Doutor João Maia Loureiro and Dr. Ernesto Galeão Roma. Francisco Gentil was a well renowned physician that played a key role in the establishment of the Portuguese Institute of Oncology founded in 1923. The first meeting of the Junta Consultiva took place on the July 26, 1944 at the Portuguese Red

\footnotetext{
${ }^{32}$ RODRIGUEZ NOZAL, Raul - 'El Despacho de Penicilina En La España: De Las Restricciones Y El Estraperlo', Revista Panacea - Humanidades, Ciencia Y Sanidad, 1, Janeiro (2015), pp. 14-15.

33 ARQUIVO DA CRUZ VERMELHA PORTUGUESA - 'Ata Da Sessão Ordinária Da Comissão Central Da Cruz Vermelha Portuguesa Em 8 de Maio de 1944', op. cit.

${ }^{34}$ ARQUIVO DA CRUZ VERMELHA PORTUGUESA - 'Carta Do Delegado Da Cruz Vermelha Americana de 05 de Maio de 1944 - Número de Ordem de Entrada 1715', Livro de Correspondência Recebida. Lisboa, 1944.

${ }^{35}$ ARQUIVO DA CRUZ VERMELHA PORTUGUESA - 'Carta Do Delegado Da Cruz Vermelha Americana de 01 de Julho de 1944 - Número de Ordem de Entrada 2758', Livro de Correspondência Recebida. Lisboa, 1944.

${ }^{36}$ ARQUIVO DA CRUZ VERMELHA PORTUGUESA - 'Carta Enviada Ao Dr. Armando Luzes Em 12 de Julho 1944 - Número de Ordem 3505', op. cit.

${ }^{37}$ ARQUIVO DA CRUZ VERMELHA PORTUGUESA - 'Ata Da Sessão Ordinária Da Junta Consultiva Da Cruz Vermelha Portuguesa Para a Distribuição Da Pencilina Em Portugal de 26 de Julho de 1944', Livro de Atas Da Junta Consultiva Da Cruz Vermelha Portuguesa Para a Distribuição de Penicilina Em Portugal. Lisboa, 1944.
} 
Cross headquarters in Lisbon. The Vice-President of the Portuguese Red Cross and members of the American Red Cross attended the meeting. The attending members discussed the best procedures to allocate, distribute and store penicillin. They also discussed and agreed upon the need to create a questionnaire to requisition of penicillin. The Junta determined that the antibiotic should be stored in the Instituto Português de Oncologia (Portuguese Institute of Oncology) and that physicians who wished to request penicillin would have to fill in the questionnaire and provide their patient's clinical details. Furthermore, the attending members decide that physicians should be provided with information regarding the correct use of penicillin and that no information be released to the press, at present.

Negotiations with the American government were successful and on September 2, 1944, the American Red Cross Delegate informed the Portuguese Red Cross that the first allotment of penicillin should arrive $\operatorname{soon}^{38}$. On September 8, 700 vials, containing 100000 units of penicillin, arrived at Lisbon airport, transported by Pan American Airways $^{39}$. The initial monthly quota of penicillin allocated to Portugal was 700 vials, in January 1945 the allotment was increased to 1000 vials $^{40}$ and in March 1945 to 1500 vials $^{41}$.

The official ceremony regarding the delivery of the first allotment of penicillin from the United States took place on September 18, 1944, at the Portuguese Red Cross headquarters in Lisbon ${ }^{42}$. The American ambassador, Henry Norweb, the President of the Portuguese Red Cross and the members of the Junta Consultiva para a Distribuição da Penicilina em Portugal were present at the ceremony. In a statement to the Portuguese newspaper Diário de Lisboa (Lisbon Daily) the American diplomat referred that Portugal was one of the first countries not at war to receive penicillin for civilian

\footnotetext{
38 ARQUIVO DA CRUZ VERMELHA PORTUGUESA - 'Carta Do Delegado Da Cruz Vermelha Americana Em 02 de Setembro de 1944 - Número de Ordem de Entrada 3728', Livro de Correspondência Recebida. Lisboa, 1944.

39 ARQUIVO DA CRUZ VERMELHA PORTUGUESA - 'Carta Enviada À Direção Geral de Saúde Pública Em 09 de Setembro de 1944 - Número de Ordem 4394', Livro de Correspondência Expedida, Volume VII. Lisboa, 1944.

${ }^{40}$ ARQUIVO DA CRUZ VERMELHA PORTUGUESA - 'Carta Da Embaixada Dos Estados Unidos Da América de 22 de Janeiro de 1945 - Número de Ordem 6718', Livro de Correspondência Recebida. Lisboa, 1945.

${ }^{41}$ ARQUIVO DA CRUZ VERMELHA PORTUGUESA - 'Carta Enviada À Cruz Vermelha Americana Em 10 de Abril de 1945 - Número de Ordem 1483', Livro de Correspondência Expedida, Volume III. Lisboa, 1945.

42 ARQUIVO DA CRUZ VERMELHA PORTUGUESA - 'Carta Enviada À Direcção Dos Serviços de Censura Em 19 de Setembro 1944 - Número de Ordem 4482', Livro de Correspondência Expedida, Volume IX. Lisboa, 1944.
} 
use and that the Portuguese medical corps would undoubtingly provide a valuable contribution to the history of the antibiotic ${ }^{43}$. Henry Norweb was one of the main participants in the negotiations held, during the summer of 1944, between the United States and Portuguese governments regarding the usage of the Lages Airfield in the Azores by American troops ${ }^{44}$.

\section{Conclusion}

Penicillin first arrived in Portugal in May 1944. Insistent appeals from the Portuguese Red Cross to Brazil, Great Britain and the United States of America resulted in arrival of twelve vials of penicillin on 24 May 1944 offered by the Brazilian government. The antibiotic supplied led to the recovery of a patient, rendering the first use of penicillin in Portugal a success. The Portuguese Red Cross perceived that a regular supply of the antibiotic was necessary and in order to attain their purpose they requested assistance from one of the major penicillin producing countries, the United States of America. Negotiations with the American government were successful and in September 1944, the first allotment of penicillin arrived at Lisbon airport. In accordance with an imposed condition by the American government, the Portuguese Red Cross appointed a controlling committee, the Junta Consultiva para a Distribuição de Penicilina em Portugal, to organize and supervise the distribution of penicillin in Portugal. The procedures implemented by the Junta Consultiva were admirable, every phase of the process was exemplary organized and permitted that the scarce amount of penicillin available was accessible to those in desperate need of treatment.

\footnotetext{
43 'O Embaixador Dos Estados Unidos Entregou À Cruz Vermelha Portuguesa Uma Remessa de Setenta Milhões de Unidades de Penicilina', Diario de Lisboa, 19 Setembro 1944, p. 4.

44 PEREIRA, Bernardo Futscher, A Diplomacia de Salazar (1932 - 1949), $2^{\text {a }}$ edição. Alfragide : Publicações Dom Quixote, 2012. ISBN 9789722051811.
} 


\section{Sources and Bibliography}

\section{I. Sources}

\section{Historical archives consulted}

Arquivo da Cruz Vermelha Portuguesa (Lisboa) / Portuguese Red Cross historical archive (Lisbon) - ACVP

Livro de correspondência expedida, Volume III. Lisboa : 1944

—Carta enviada à Cruz Vermelha Brasileira em 27 de Março 1944, número de ordem 1368.

- Carta enviada à Embaixada do Brasil em 27 de Março 1944 - Número de ordem 1374.

—Carta enviada à Cruz Vermelha Americana em 10 de Abril de 1945 - Número de ordem 1483.

Livro de correspondência expedida, Volume VII. Lisboa : 1944

- Carta enviada à Direção Geral de Saúde Pública em 09 de Setembro de 1944 Número de ordem 4394.

Livro de correspondência expedida, Volume VIII. Lisboa : 1944

—Carta enviada ao Dr. Armando Luzes em 12 de Julho 1944 - Número de ordem 3505.

Livro de correspondência expedida, Volume IX. Lisboa : 1944

—Carta enviada à Direcção dos Serviços de Censura em 19 de Setembro 1944 Número de ordem 4482.

Livro de correspondência expedida, Volume X. Lisboa : 1944 
—Carta enviada à Delegação da Cruz Vermelha Portuguesa de Estremoz em 20 de Setembro 1944 - Número de ordem 4524.

\section{Livro de correspondência expedida}

— Telegrama enviado à Cruz Vermelha Brasileira em 24 de Maio 1944.

Livro de correspondência recebida. Lisboa : 1944

— Carta da Embaixada Britânica de 09 de Maio de 1944 - Número de ordem de entrada 1800.

—Carta da Legação dos Estados Unidos da América de 19 de Abril de 1944 - Número de ordem de entrada 1445 .

- Carta do Delegado da Cruz Vermelha Americana de 05 de Maio de 1944 - Número de ordem de entrada 1715 .

- Carta do Delegado da Cruz Vermelha Americana de 01 de Julho de 1944 - Número de ordem de entrada 2758.

- Carta do Delegado da Cruz Vermelha Americana em 02 de Setembro de 1944 Número de ordem de entrada 3728.

- Carta da Embaixada dos Estados Unidos da América de 22 de Janeiro de 1945 Número de ordem 6718.

Livro de atas da Comissão Central da Cruz Vermelha Potuguesa. Lisboa : 1944

—Ata da Sessão Ordinária da Comissão Central da Cruz Vermelha Portuguesa em 8 de Maio de 1944.

—Ata da Sessão Ordinária da Comissão Central da Cruz Vermelha Portuguesa em 12 de Junho de 1944.

Livro de atas da Junta Consultiva da Cruz Vermelha Portuguesa para a Distribuição de Penicilina em Portugal. Lisboa : 1944

- Ata da Sessão Ordinária da Junta Consultiva da Cruz Vermelha Portuguesa para a Distribuição da Pencilina em Portugal de 26 de Julho de 1944.

\section{Bibliography}


BELL, Victoria - Introdução dos antibióticos em Portugal: ciência, técnica e sociedade (anos 40 a 60 do século XX). Estudo de caso da penicilina. Coimbra: Tese de doutoramento - Universidade de Coimbra, 2014.

BELL, V., PITA, J. R.; PEREIRA, A. L. - “A importância do Brasil no fornecimento das primeiras doses de penicilina para Portugal (1944)". In: FIOLHAIS, C.; SIMÕES, C.; MARTINS, D. (eds.), Congresso Luso-Brasileiro de História das Ciências. Livro de Actas, Coimbra, 2011. ISBN 978-989-26-0122-9. p. 878-891.

BELL, Victoria; PITA, João Rui; PEREIRA, Ana Leonor — "Circuitos e redes de distribuição da penicilina em Portugal: 1944-1946. In: MALAQUIAS, Isabel et al. — Construir Ciência - Construir o Mundo. Aveiro: UA Editora - Universidade de Aveiro, 2014. ISBN 978-972-789-418-5. p. 143-145.

BUD, Robert - Penicillin Triumph and Tragedy, Oxford: Oxford University Press, 2007. ISBN 978-19-925406-4

CARRILHO, Maria et al - Portugal na Segunda Guerra Mundial: contributos para uma reavaliação. Lisboa: Dom Quixote, 1989. ISBN 972-20-0755-6

GONZÁLEZ BUENO, Antonio; RODRIGUEZ NOZAL, Raul - La penicilina en la España franquista: importación, intervención e industrializaciónitle. Revista EIDON. ISSN 2174-8292. 38 (2002).

GONZÁLEZ BUENO, Antonio; RODRÍGUEZ NOZAL, Raul; TEIJÓN, Carlos José Pérez - "La penicilina en Espanã: difusión, propriedad industrial y negocio, en clave autárquica (1944-1959)”, Estudos do Século XX. ISSN 1645-353. 12 (2012), 271-287.

GROSSMAN, Charles M. - "The First Use of Penicillin in the United States". Annals of Internal Medicine. ISSN 1539-3704. 149 (2008), 135-136.

HELFAND, W. H. et al.- "Wartime industrial development of penicillin in the United States." In: PARASCANDOLA, John - The history of antibiotics. A Symposium. 
Madison: American Institute of the History of Pharmacy, 1980. ISBN 100931292085 ISBN 139780931292088 p 31-56.

LAX, Eric - The Mold in Dr. Florey's Coat. The story of the penicillin miracle. New York: Owl Books, 2005. ISBN-13 978-0805077780; ISBN-10 0805077782

LEDERMANN, Walter D. - "La historia de la penicilina y de su fabricación en Chile". Revista Chilena de Infectología. ISSN 0716-1018. 23:2 (2006), 172-176.

LESCH, John E. - The First Miracle Drugs: How the Sulfa Drugs Transformed Medicine. New York : Oxford Univ Press, 2007. ISBN 139780195187755.

MINISTÈRE DE LA SANTÉ PUBLIQUE - Thérapeutique par la Pénicilline. Primiere ed. Paris : Masson et Cie, Éditeurs, 1947.

O embaixador dos Estados Unidos entregou à Cruz Vermelha Portuguesa uma remessa de setenta milhões de unidades de penicilina - Diario de Lisboa. (19 set. 1944). 4.

Penicilina em Portugal - Jornal do Médico. 4:93 (1944) 709.

Penicillin: A Wartime Accomplishment - Chemical \& Engineering News. 23:24 (1945) 2310-2316.

PEREIRA, Bernardo Futscher - A diplomacia de Salazar (1932 - 1949). $2^{\text {a }}$ Edição ed. Alfragide : Publicações Dom Quixote, 2012. ISBN 9789722051811.

RODRIGUEZ NOZAL, Raul - El despacho de penicilina en la España: de las restricciones y el estraperlo. Revista Panacea - Humanidades, Ciencia y Sanidad. 1:Janeiro (2015) 14-15.

TORGAL, Luís Reis - Estados Novos, Estado Novo. Vol. 2. Coimbra: Imprensa da Universidade de Coimbra, 2009. ISBN 978-989-8074-60-7. 
TORGAL, Luís Reis; PAULO, Heloísa (coords.) - Estados autoritários e totalitários e suas representações. Coimbra: Imprensa da Universidade de Coimbra, 2008. ISBN 979-989-8074-53-9.

SANTESMASES, M. J. - "Distributing Penicillin: the clinic, the hero and industrial production in Spain, 1943-1952”. In: QUIRKE, V.; SLINN, J. (eds.) - Perspectives on Twentieth-Century Pharmaceuticals. Oxford: Peter Lang, 2010. ISBN 978-3-03910920-3. p. 91-118.

SANTESMASES, M. J. - "Screening antibiotics: industrial research by CEPA and Merck in the 1950s”. Dynamis. ISSN 0211-9536. 31:2 (2011), 407-427.

WAINWRIGHT, M. - The history of the therapeutic use of crude penicillin. Medical History . ISSN 0025-7273. 31:1 (1987) 41-50. 